\title{
OGRANIČENJE REGULACIJSKE FUNKCIJE DRŽAVE PUTEM MEĐUNARODNIH INVESTICIJSKIH UGOVORA
}

\author{
UDK: 341 \\ DOI: $10.31141 /$ zrpfs.2019.56.133.719 \\ Pregledni znanstveni rad \\ Primljeno: 1. 10. 2018.
}

Proces globalizacije stavlja države, pa time i njihove uprave, pred nove izazove, koji se jedino mogu savladati međusobnom saradnjom država i drugih subjekata međunarodnog prava. Međuovisnost navedenih subjekata u globalnoj ekonomskoj utrci i borba za investicijama proizvela je i nove oblike upravne regulacije, prije svega, pojavom međudržavnih bilateralnih i multilateralnih investicijskih ugovora, koji u bitnome utiču na upravno-pravnu sferu država, tj. ograničavaju kako po obimu tako i po kvalitetu regulacijske mogućnosti država. Ipak, ne može se zanemariti činjenica da države i dalje predstavljaju personifikaciju moći i vlasti.

Sa druge strane, ograničenja države da autonomno donosi odluke u korist javnog interesa posebno su vidljiva kod međunarodnih investicijskih ugovora. Uvođenjem međunarodnih arbitraža za rješavanje investicijskih sporova, kao međunarodnim tijelima, omogućava se istima da prilikom donošenja odluka ocjenjuju cjelishodnost propisa kojima država nastoji da zaštiti javni interes. Međunarodne investicijske arbitraže, za razliku od ranijih međunarodnih tribunala i sudova, imaju ulogu kvazi-zakonodavca, a ta uloga je im omogućena zbog široko i neprecizno formulisanih odredbi investicionih ugovora, koje dozvoljavaju arbitražama veliki prostor za tumačenje i diskrecionu ocjenu. Sve to dovodi ozbiljno u pitanje regulacijske kapacitete države.

Ključne riječi: suverenitet, regulacija, država, međunarodni investicijski ugovori, međunarodne investicijske arbitraže

\section{UVOD}

Uloga države u svim fazama njenog razvoja sastojala se od temeljnog suverenog prava da vrši vlast i reguliše društvene odnose u okviru određenog društva. Međutim, proces globalizacije stavlja države, pa time i njihove uprave, pred nove izazove, koji se jedino mogu savladati međusobnom saradnjom država i drugih subjekata međunarodnog prava. Time se otvaraju vrata novim procesima koji državama nameću obaveze da prilikom vršenja svojih suverenih prava, regulacije društvenih odnosa, uzmu u obzir i legitimna prava drugih država i subjekata međunarodnog prava. Naime, međuovisnost navedenih subjekata u globalnoj ekonomskoj utrci i

1 Dr. sc. Mahir Muharemović, Program vladavine prava za Jugoistočnu Evropu Konrad Adenauer Fondacije, Str. Franzelarilor nr.5, sector 2, Bukurešt, e-mail: Mahir.Muharemovic@kas.de 
borba za investicijama proizvela je i nove oblike upravne regulacije, prije svega, pojavom međudržavnih bilateralnih i multilateralnih investicijskih ugovora, koji u bitnome utiču na upravno-pravnu sferu država, tj. ograničavaju kako po obimu tako i po kvalitetu regulacijske mogućnosti država.

Upravo navedeno će biti predmet razmatranja u nastavku ovog rada, sa ciljem da se utvrdi stepen intruzivnosti investicijskih ugovora u sferu prerogativa država da svojim normativnim, a posebno upravno-pravnim, mehanizmima upravljaju tokovima jednog društva u korist općeg dobra, a naspram legitimnih interesa i zahtjeva stranih investitora za zaštitom investicija. U tom smislu, u nastavku, treba sagledati razvoj misli o samoj ulozi države i njene uprave kroz vijekove, analizirati uticaj filozofije ekonomskog liberalizma na upravno-regulacijsku funkciju države, te i konkretan uticaj samih odredbi investicijskih ugovora kao i prakse međunarodnih arbitraža, koje djeluju na osnovu takvih ugovora, na upravno-regulacijsku funkciju država.

\section{ULOGA SAVREMENE DRŽAVE KAO PRUŽATELJA JAVNIH USLUGA}

Prije sagledavanja države kao glavnog regulatora društva, nužno je analizirati, ukratko, državu kao sociološku pojavu, odnosno, kako to navodi Lukić (1979), kao društvo nad društvom. Država je najznačajnija politička institucija u društvu. Prema njoj se usmjeravaju interesi svih društvenih grupa i pojedinaca izazivajući socijalne, ideološke i političke odnose kroz sukobe i saradnju. U državi se, kao u ogledalu, prelamaju svi odnosi, karakteristike, usponi i padovi jedne društvene zajednice. Država je institucija koja prožima sve društvene grupe i njihove odnose. Ona se izdvaja iz društva kao autonomna sila koja svojim autoritetom i instrumentima donosi (nameće) opća pravila i nastoji da obezbijedi skladno funkcionisanje i održavanje društvenog poretka. Ako pođemo od etimološkog tumačenja, vidimo da na mnogim jezicima riječ država znači stanje, položaj, postaviti, odrediti, narediti, utvrditi, preduzeti (lat. statio, ital. stato, špan. estado, fran. etat, nem. Staat, eng. state ). Na nekim slovenskim jezicima riječ država se može izvesti od glagola držati, održavati ("država", "dežela"). Svako držanje, stanje, položaj treba uspostaviti, čuvati i održavati, ali i mijenjati i nanovo uspostavljati, a za to je potrebna i sila i dobrovoljni pristanak onih na koje se to odnosi. Državu možemo odrediti kao najznačajniji oblik pravno-političkog organizovanja stanovništva koje živi na određenoj teritoriji. To je najviši oblik političke, javne, suverene vlasti na određenoj teritoriji. Ovo poimanje države više je sa pravnog stanovišta, dok za sociološki pogled na državu treba dodati da je država prostor, polje na kome se takmiče (bore) različite društvene grupe i organizacije kako bi ostvarili svoje interese kroz interakciju punu socijalnih, političkih, ideoloških i drugih tenzija i konflikata. Država organizuje i održava vlast na dva načina: prinudom i dobrovoljnim pristankom stanovnika, građana, "podanika". Neophodno je da postoji ravnoteža između ova dva oblika 
organizovanja i održanja vlasti, kako ne bi došlo do nasilja od strane države ili nepoštivanja pravila od strane građana. (Šijaković, 2008, ss. 131-132)

Međutim, bez obzira na teorijsko-ideološke poglede na državu, sama djelatnost regulacije pravnim normama obilježje je institucije države od samih početaka njezina nastanka (Pusić, 1989, s. 307). Prema nekim autorima (Muhić, 2002) regulacijska funkcija države od samih začetaka imala je za cilj usmjeravanje glavnih procesa društvenog života $u$ onom pravcu koji je u određenom trenutku odgovarao vladajućoj klasi ili pojedinim njenim slojevima. Takva regulacija se uvijek vršila na dva načina-demokratski i diktatorski. Slično tome Lukić (1979) vidi regulacijsku ulogu države kao svojevrsnu kontrolu unutar-društvenih sukoba i suprotstavljanih interesa unutar jednog društva. Od tog vremena shvaćanja o ulozi države ciklično su se mijenjala (u smislu veće i manje dominacije u odnosu prema okolini), a njezina struktura diferencirala. To je, između ostalog, dovelo i do strukturne diferencijacije regulativnih organizacija pri čemu zadatke regulacije preuzimaju i organizacije koje nisu neposredno povezane sa državno-političkom sferom (Pusić, 1989, s. 230). Država obnaša regulacijsku ${ }^{2}$ funkciju i nakon prijelaza sa monarhove vladavine na vlast koja izvire iz naroda, ali ovaj put to čini putem nosioca podijeljenih funkcija jedinstvene vlasti. U takvom sistemu normativne regulacije uspostavlja se hijerarhija pravnih normi te sistem provjera i ravnoteža između pojedinih vršitelja državne vlasti. (Džinić, 2011, s.652)

Slijedom navedenog, napušta se i shvatanje funkcije države i njene uprave kao vršenje vlasti te se prelazi na koncept javnih službi. Nasuprot "državnom" i "klasnom" modelu uprave, modeli uprave koji danas preovladavaju u razvijenim zemljama (posebno evropskim) proizilaze iz koncepcije socijalne funkcije države i uprave i njihove uloge u ostvarivanju opšteg interesa i društvene dobrobiti (bono publico). Koncept socijalne funkcije, odnosno društvene uloge uprave, polazi od toga da se vršenje upravnih aktivnosti države ne može svesti isključivo na vršenje državne vlasti (u smislu izdavanja zapovjedi i vršenja radnji prinude prema svojim podanicima), već da vršenje upravnih aktivnosti, prije svega, podrazumijeva vršenje javnih službi, kao aktivnosti kojima se ostvaruju i obezbjeđuju uslovi koji su građanima neophodni za njihov svakodnevni život i rad i koje doprinose opštem razvoju i napretku društva kao cjeline. (Lilić, 2014, s. 32)

Koncept javnih službi razvio se ponajprije u francuskoj upravnoj teoriji te kroz sudsku praksu Državnog savjeta (Conseil d'Etat) kao najvišeg upravnog suda u Francuskoj. Leon Duguit u knjizi Les transformations du droit public (1905) smatra da državu legitimira obavljanje javnih službi - službi u interesu stanovnika i zajednice u kojoj žive, a javnu službu definira kao ,djelatnost čije vršenje upravljači trebaju regulirati, osigurati i kontrolirati, pošto je ona neophodna za ostvarenje i razvitak uzajamne društvene ovisnosti i takve je prirode da može biti potpuno osigurana samo posredovanjem sile kojom raspolažu upravljači“ (Duguit, 1929, s. 51). Ovaj

2 Iako se izrazu "regulacija" pridaje niz različitih značenja, u radu se polazi od Pusićeve definicije regulacije kao "djelatnosti sistematskog legitimnog utjecaja na ponašanje ljudi prema prethodno postavljenim kriterijima“" (Pusić, 1989., s. 149). 
koncept je rezultat nastanka ideologije socijalne države. Socijalna država nastaje od kraja 19. stoljeća kad ta institucija počinje preuzimati sve veći broj javnih službi, odnosno financijske, organizacijske, personalne i druge terete osiguranja određenog minimuma javnih usluga koje se pod jednakim uvjetima pružaju svim članovima zajednice bez naplate ili uz naplatu minimalnog dijela stvarne cijene te usluge. Javnim je službama u prvom redu interes stanovnika, a ne države. Javne službe pružaju javnopravni pružatelji, tj. organizacije tipa (neprofitnih) javnih ustanova ili (profitnih) javnih poduzeća, koje osniva država i u vlasništvu su države (centralna država ili jedinice lokalne samouprave). Građani dobivaju ulogu korisnika usluga javnih službi. Javne službe obavljaju se u općem interesu, a regulirane su javnim pravom (Koprić, b.d., s. 2). Socijalna država je obilježena ponajprije društvenim službama, kao što su javno obrazovanje, zdravstvo, kultura, socijalna skrb i zaštita, te različitim vrstama osiguranja (za slučajeve bolesti, starosti, nezaposlenosti, invaliditeta, i dr.). Ona je preuzela i službe koje povećavaju kvalitetu života uopće, kao što su komunalne, informacijske (katastarska, meteorološka, itd.), tehničke (pošta, telefon, željeznički, riječni, morski i druge vrste javnog prijevoza, opskrba električnom, toplinskom i drugim vrstama energije, itd.), i druge službe. Rast i širenje javnih službi i socijalne države obilježili su veći dio 20. stoljeća, sve do ekonomske krize sredinom 1970-ih (Koprić, b.d., s. 2). Posebno nakon Drugog svjetskog rata sve se više razvija koncepcija sveprisutne države utemeljena na potrebi ponovne izgradnje razorene ekonomske i društvene osnove europskih država. Tu koncepciju države obilježava razvoj institucija socijalne države (eng. welfare state), a javna se uprava ${ }^{3}$ temelji na idealnom tipu veberijanske uprave, kao što su urednost, monokratsko-birokratska organizacija, djelovanje na temelju propisa, važnost procesa, prava i senioriteta u državnoj službi (Friedrich Ebert Stiftung, 2014, s. 10).

Među glavnim razlozima za intervenciju regulacijom ističe se ispravljanje nesavršenosti djelovanja tržišta kao regulacijskog mehanizma (Majone, 1996, s. 28). Naime, suprotno stajalištu da slobodno tržište vodi efikasnoj alokaciji resursa, pokazalo se da je radi prevladavanja neuspjeha tržišta ( eng.market failures) i zaštite javnog interesa potrebno primijeniti niz instrumenata regulacije koji se međusobno razlikuju po stepenu državne intervencije u određenom području.

\section{ZAŠTITA MEĐUNARODNIH INVESTICIJA PUTEM MEĐUNARODNIH INVESTICIJSKIH UGOVORA}

U oblasti međunarodnih investicija ne postoji nijedan multilateralni sporazum ekvivalentan Sporazumu o uspostavljanju Svjetske trgovinske organizacije kao i drugih sporazuma pod okriljem Svjetske trgovinske organizacije (vidi: Ding,2016).

3 Ovdje treba istaći da se u teoriji modeli države i javne uprave klasificiraju po različitim kriterijima, ali najpotpuniju klasifikaciju nalazimo kod Koprića et al. (2014, ss. 40-45) prema kojoj razlikujemo vestminsterski (anglosaksonski) model, veberijanski ili germanski (organicistički) model, napoleonski ili francuski (južnoevropski) model te skandinavski (nordijski) model države i javne uprave. 
Ipak, pravna žaštita strane imovine ima dugu historiju u međunarodnom pravu, a najčešće je ova oblast regulisana međunarodnim običajnim pravom ( vidi: Aaken, 2009, s. 3; vidi :Ding, 2016).

Međunarodni pravni okvir za zaštitu inostranih ulaganja ${ }^{4}$ sastoji se od mreže međunarodnih ugovora o zaštiti ulaganja, te pravila običajnog prava i drugih normi međunarodnog prava koja se primjenjuju in subsidio. Najvažniji izvor prava u međunarodnoj arbitražnoj praksi su dvostrani međunarodni ugovori o poticanju i zaštiti ulaganja ( eng. bilateral investment treaties - skrać. BIT's) Osim dvostranih ugovora, sklopljen je i manji broj višestranih ugovora od kojih su neki sektorske (npr. Ugovor o Energetskoj povelji), a drugi regionalne naravi (npr. NAFTA, ASEAN). "Međunarodni ugovori o zaštiti ulaganja s jedne strane propisuju materijalno- pravne standarde zaštite ulaganja stranih državljana i društava, a s druge strane procesno-pravne mehanizme za ostvarenje te zaštite u arbitražnom ili sudskom postupku" (Babić, 2012, s.399).

Naime, međunarodni investicijski ugovori sadrže dvije temeljne inovacije, koje su odstupile od dotadašnjih rješenja. Prva inovacija se sastoji od toga da se takvim ugovorima stranim investitorima dodjeljuje niz supstancijalnih prava koja pomažu pri stabilizaciji investicijske klime, dok druga inovacija omogućava investitorima da se radi zaštite svojih supstancijalnih prava obrate direktno međunarodnim arbitražama (Franck, 2005, s. 1529).

Iz pravne perspektive, struktura i sadržaj BIU-ova obično je slična širom svijeta. Ključni elementi koji se nalaze u svim takvim ugovorima obuhvaćaju odredbe koje se bave s opsegom primjene; dozvolom za ulaganje, poštenim i pravednim postupanjem; nacionalnim tretmanom investitora, eksproprijacija i naknadama za eksproprijacije i načinom rješavanja sporova (Yannaca-Small, 2010, s.6). Određena odstupanja u pogledu dodijeljenih prava i obaveza su rezultat samih pregovora između država. Općenito, države se investicijskim ugovorima obavezuju da će štititi ulaganja investitora druge države ugovornice. Međunarodni investicijski ugovori su, po svojoj strukturi, ugovori sa zaštitnim dejstvom u korist trećeg lica- investitora (Binder, 2013, s. 592 ). U suštini, ugovori se bave pitanjima prava koja se dodjeljuju investitorima, vrstama investicija koje su zaštićene i od kada sama zaštita počinje i kada se završava.

Međunarodni investicijski ugovori u međunarodnom investicijskom pravu imaju vitalnu ulogu, odnosno predstavljaju motor koji pokreče i ubrzava investicije u određenim državama. Tako primarna funkcija investicijskih ugovora leži u povećanju ekonomske kompetitivnosti država kroz pojačanu zaštitu stranih ulagača.

${ }_{4}$ Strana investicija uključuje transfer materijalnih ili nematerijalnih sredstava iz jedne zemlje u drugu u svrhu njihove upotrebe u toj zemlji za stvaranje bogatstva pod potpunom ili djelimičnom kontrolom vlasnika imovine (Sornarajah, 2010, s.8). Međunarodno pravo pravi razliku između stranih direktnih investicija i portfolio investicija. Portfolio investicije, kao što je kupovina stranih dionica, obveznica ili drugih instrumenata, uglavnom ne potpadaju pod opseg međunarodnog prava i stoga nisu zaštićeni međunarodnim običajnim pravom. Moguće je da se uključuje portfolio investicije pod režim stranih investicija kroz ugovore, kao što su bilateralni investicijski ugovori i ugovori između država i investitora (Roeder, 2016, s. 19). Više o ekonomskoj prirodi i vrsti investicija vidu u: MacNeil, 2005. 
Prethodno navedeno posebno ukazuje na okolnost „da je nacionalna država, zbog globalizacijskih procesa, izgubila dio funkcionalnosti u regulatornom smislu, i kako takva, postala dijelom ovisna o globalnim privrednim kretanjima. S jedne strane, nacionalne su države bile snažno usmjerene ka međusobnom natjecanju u privlačenju kapitala, i jačanju ukupne nacionalne konkurentnosti, u globalnim okvirima“ (Lozina \& Klarić, 2012, s.24). Takav trend je doveo do snažne ekspanzije bilateralnih i multilateralnih investicijskih ugovora, kao svojevrsnog oblika zaštite stranih investicija, a koji predstavljaju često dodatni faktor konkurentnosti država za privlačenje stranih investicija. Tako Schreurer (b.d.,s.1) navodi da strane investicije podržavaju i ubrzavaju pristup svjetskim tržištima, dovode do širenja distribucijskih kanala, te u znatnome doprinose izgradnji i jačanju infrastrukture država u razvoju. Generalno govoreći, „države zaključuju investicijske ugovore samo kada su očekivani troškovi, koji se sastoje u ograničenju regulatornog suvereniteta država, manji od očekivane dobiti“" (Aaken, 2009, s. 3).

Potpisivanjem međunarodnog investicijskog ugovora država se pravno obavezuje da se podvrgne pravilima koja ograničavaju njeno buduće djelovanje u pogledu strane investicije (Bonnitcha, 2015). Preciznije, gledajući iz perspektive stranog investitora, svrha međunarodnih investicijskih ugovora je da "stvori međunarodni režim minimalnih standarda za korištenje suverenih ovlasti države- domaćina u odnosu na investicije učinjene na njenoj teritoriji, a koje potiču iz država ugovornica “(Douglas, 2009, s.1).

Konkretno, zaštita stranih investitora ostvaruje se kroz odredbe međunarodnih investicijskih ugovora koje omogućavaju direktan pristup investitora međunarodnoj arbitraži, garanciju supstancijalnih prava u vidu standarda zaštite, brz i efikasan postupak pred arbitražama čije odluke ne podliježu posebnoj kontroli nacionalnih sudova i čije odluke su izvršne i koje ne predviđaju posebne obaveze za strane investitore. U nastavku ovog poglavlja analizirat ćemo pravo investitora na pristup arbitražnim tribunalima kao i pitanje nepostojanja posebnih obaveza stranih investitora prema odredbama investicijskih ugovora.

\section{DEJSTVO MEĐUNARODNIH INVESTICIJSKIH UGOVORA NA REGULACIJSKU FUNKCIJU DRŽAVE}

Što se tiče konkretno uticaja međunarodnih investicijskih ugovora, koji svi baštine principe liberalizacije tržišta i privatizacije javnog sektora, na upravnoregulacijsku sposobnost država, treba primijetiti da isti jasno limitiraju suverena prava države-domaćina da stranog investitora podvrgne domaćem sistemu regulacije. Naime, ovo je rezultat bojaznosti investitora da će njihove investicije biti podvrgnute nepredvidljivom i nestabilnom pravnom okviru države-domaćina. Po pravilu, garancije koje se daju investitorima tim ugovorima su dodatak na već postojeće garancije u nacionalnim pravnim sistemima. Uticaj na domaće pravo uslijed prihvatanja takvog režima danas se smatra normalnim i nužnim za stvaranje 
povoljne klime za strane investicije. Dakle, prioritet država se promijenio, odnosno privlačenje investicija ima prioritet $u$ odnosu na suverenitet. U tom pogledu, uvođenjem mehanizma rješavanja sporova pred arbitražnim tribunalima, napušta se tradicionalni princip međunarodnog prava da se samo države -ugovornice mogu obratiti međunarodnim tribunalima, jer investicijski ugovori predviđaju pravo investitora da se obrati takvom tribunalu. Time zakoni države- domaćina postaju predmet međunarodne revizije po volji stranog investitora. (Dolzer, 2005a, s. $953 \mathrm{i}$ 957) Ovakav model promoviše neoliberalne vrijednosti putem nadnacionalnog prava koje direktno ili indirektno utiče i mijenja nacionalne pravne sisteme (Schneiderman, 2013, s. 40). Ipak, ovdje treba istaći da ne postoji niti jedan međunarodni investicijski ugovor koji formalno daje ovlast međunarodnim arbitražama da ponište legislativne akte države-domaćina (Carvalho, 2016, s.20).

Brojne materijalno-pravne odredbe investicijskih ugovora koje utiču na domaći pravni sistem imaju svoje porijeklo u međunarodnom pravu. Djelimično su rezultat autonomnog, ugovorom uspostavljenog, prava, a djelimično se temelje na međunarodnom običajnom pravu, na koje se pozivaju predmetni ugovori, a koje je čak primjenjivo i u odsustvo takve ugovorne odredbe. U svim tim ugovorima, obje vrste materijalnog prava su predmet interpretacije i primjene od strane međunarodnih tribunala. Kao rezultat toga, moć da se identifikuju, primjene i izvrše takva pravila je prešla sa država na međunarodne tribunale, na što su dobrovoljno pristale same države-ugovornice. U tom smislu, međunarodno investicijsko pravo nastoji izolirati inostrana ulaganja od društvenog ugovora koji prevladava u određenom društvu. Arbitraža stvara jedinstveni prostor za međunarodni nadzor državnog ponašanja: tribunali koji obično čine tri privatne osobe preispituju ponašanje demokratski izabranih vlada ili zakonodavnih tijela ili nacionalnih sudova na temelju široko formuliranih standarda sporazuma koji ostavljaju veliku diskreciju arbitražnim tribunalima. Arbitražni tribunali značajno su doprinijeli razvoju međunarodnog investicijskog prava, razvijanjem ključnih koncepata zaštite ulaganja kao što su "legitimna očekivanja" i tumačenjem standarda tretmana stranih investicija u pravcima koji nisu uvijek predviđeni od strane država-ugovornica. Važnost arbitražne sudske prakse u oblikovanju međunarodnog investicijskog prava donekle je neizbježna s obzirom na nejasnu formulaciju mnogih ugovora o ulaganju.(Cotula, 2014)

U praksi, prema Dolzeru (2005a, s. 957) tri vrste klauzula, sadržanih u investicijskim ugovorima, imaju najveći uticaj na domaći pravni sistem. To su:

- klauzule koje uspostavljaju pravila vezana za indirektnu eksproprijaciju,

- klauzule koje zahtijevaju "pošten i pravičan" tretman stranih investitora, i

- klauzule o zaštiti investicijskih ugovora zaključenih između stranih investitora i države-domaćina, tzv. kišobran klauzula.

Investicijski ugovori koriste razne definicije za indirektnu eksproprijaciju. Neki ugovori definišu istu kao mjere "ravne" direktnoj eksproprijaciji, a drugi kao mjere koje imaju "isto dejstvo" kao direktna eksproprijacija. Bez obzira na definiciju, jasno je da takve zaštitne odredbe o indirektnoj eksproprijaciji predstavljaju značajnu 
restrikciju suverenog prava država-domaćina da regulišu određene oblasti kao npr. ekonomiju, zaštitu okoliša, poreze i radno pravo, jer primjena takvih odredbi ovisi jedino o tumačenju međunarodnih tribunala. (OECD, 2004)

Zahtjev "poštenog i pravičnog" tretmana stranog investitora je standardna odredba modernih investicijskih ugovora. Međutim, razrada takvog standarda je također raznolika. Jedna grupacija država (posebno Njemačka, Svajcarska i Svedska) ovaj standard posebno razrađuju u ugovornim odredbama, dajući mu autonomno značenje, dok druga grupa država (posebno SAD, Velika Britanija i Francuska) razradu navedenog standarda podvode pod pravila međunarodnog prava, pa time i međunarodnog običajnog prava. Shodno navedenom, arbitražni tribunali su na osnovu navedenog standarda izveli zahtjev za stabilnošću, konzistentnošću i transparentnošću administrativnih pravila i radnji države domaćina. (UNCTAD, 2012) Na to pitanje, arbitražni tribunali istakli su da je jedna temeljna obveza u ugovorima o ulaganju - obveza poštenog i pravičnog tretmana - štiti "legitimna očekivanja" ulagača u trenutku ulaganja ( vidi npr. odluku u: Técnicas Medioambientales Tecmed, S.A. v. United Mexican States, ICSID Case No. ARB(AF)/00/2, Award, May 29, 2003, para. 154.), i ako se zakonski okvir koji reguliše investiciju mijenja na način koji investitor nije predvidio ili predvidio u trenutku ulaganja, tada bi investitoru trebao nadoknaditi trošak prilagođavanja tim promjenama (vidi : Total v. Argentina, ICSID Case No. ARB/04/1, Decision on Liability, Dec. 27, 2010, para. 122.) To znači da ako se usvoji novi zakon ili se postojeći zakon opozove ili tumači ili primijeni na novi način (Occidental Exploration and Production Company v. Ecuador, LCIA Case No. UN 3467, Final Award, July 1, 2004) te promjene mogu pokrenuti pitanje odgovornosti države. Razni tribunali rafinirali su i nedvojbeno ublažili to pravilo "legitimnih očekivanja", navodeći da ugovori o ulaganju općenito ne traže "zamrzavanje" zakona, osim ako su te promjene u suprotnosti s određenom obvezom države ( tako vidu u: AES v. Hungary, ICSID Case No. ARB/07/22, Award, Sept. 23, 2010, para. 9.3.34.) U nizu slučajeva arbitražni tribunal su široko protumačili koncept "posebne obveze". U slučajevima kao što su EDFI v. Argentine (ICSID Case No. ARB/03/23 Award, June 11, 2012), Enron v. Argentina (ICSID Case No. ARB/01/3, Award, May 22, 2007), LG\&E v. Argentina (ICSID Case No. ARB/02/1, Decision on Liability, Oct. 3, 2006) i Occidental v. Ecuador (Occidental Exploration and Production Company v. Ecuador, LCIA Case No. UN 3467, Final Award, July 1, 2004) arbitražni tribunali su pronašli odredbe domaćih zakona i propisa koji sadrže takve neopozive obaveze.

Značajno je ovdje istaknuti da široko pravilo da bi vlade trebale nadoknaditi "štetu" investitorima za promjene u općem regulatornom okviru koji utječu na njihova očekivanja i profitabilnost, te time se privilegiraju privatna prava nad vladinom regulatornom slobodom nije u skladu s nacionalnim pravilima, poput onih u Sjedinjenim Američkim Državama. Tako je generalno pravilo u SAD-u, osim određenih, usko definisanih situacija, da država ne može biti odgovorna za ekonomsku štetu privatnim entitetima koja je nastala općim regulatornim promjenama u određenoj oblasti. (Johnson \& Volkov, 2014) 
Također, mnogi investicijski ugovori, kao međudržavni ugovori, sadrže tzv. kišobran klauzulu (eng. umbrella clause) kojom se države-ugovornice obavezuju da će poštovati sve obaveze koje ugovore sa stranim investitorima. Svrha ove klauzule leži u tome da se eventualno kršenje ugovorne obaveze iz ugovora zaključenog između države- domaćina i stranog investitora pretvori automatski u kršenje međunarodnog bilateralnog investicijskog ugovora od strane države domaćina u odnosu na državu iz koje potiče strani investitor. Time se stvara osnov za odgovornost države-domaćina po međunarodnom pravu, te se otvaraju vrata za međunarodnu arbitražu, ugovorenu bilateralnim investicijskim ugovorima. Ratio ove klauzule leži u namjeri da se ugovori o koncesiji podvrgnu međunarodnom pravnom okviru, odnosno da se ograniče ili isključe unilateralne regulacijske ovlasti država-domaćina u domenu koncesija. Dakle, ovom klauzulom se stavljaju ugovori o koncesiji pod "zaštitu" bilateralnih međudržavnih investicijskih ugovora, čime se u bitnome ograničava regulacijska moć država-domaćina. ( Yannaca-Small, 2006)

Ovdje treba istaći da se strani investitor, po pravilu, može osloniti na njemu dodijeljena prava na osnovu postojećeg prava (u objektivnom smislu) u trenutku investicije. Ujedno, postojeći pravni okvir države domaćina, u trenutku investicije, može poslužiti kao osnov stranom investitoru za procjenu budućih regulatornih promjena. U tom smislu, država -domaćin mora uzeti u obzir kod budućih regulacijskih koraka u određenom sektoru i aspekt legitimnih očekivanja koja su stvorena kod stranog investitora na osnovu postojećeg regulativnog okvira (Potesta, 2013).

U skladu sa navedenim, arbitražni tribunali su tumačili dvosmislenosti u ugovoru u korist potvrđivanja, a ne odbacivanja, postojanja obveze da se država odrekne buduće upotrebe suverene moći. Tako je Enron tribunal je naveo da ako je pravni okvir koji je postojao u to vrijeme "trebao biti prolazan [,] trebalo je to jasno biti stavljeno do znanja potencijalnim investitorima"(Enron Corp. v. Argentina, supra, para. 137.) Isto, tribunal EDFI-a tvrdi da bi, ako Argentina nije namjeravala podnijeti rizik gubitka za buduće regulatorne promjene, "to mogla reći" u svom ugovoru (Vidi: EDFI v. Argentina, supra, para. 960.) Oba su slučaja zahtijevala od tužene države, eksplicitno, da se suzdrži od budućeg vršenja suverene moći, te stoga su takva stajališta i praksa u suprotnosti sa nacionalnim pravnim propisima po kojima se takvo obećanje o suzdržavanju korištenja suverene moći države može samo predvidjeti ukoliko postoji obostrana namjera za takvo što koja je jasno i nedvojbeno izražena (Johnson \& Volkov, 2014).

Dakle, jasno je da investicijski ugovori, a posebno praksa arbitražnih tribunala (panela) u velikom utiče na unutrašnje procese državne uprave (Kingsbury \& Schill, 2009, s.1). U tim odlukama, arbitražni tribunali, tumače međunarodne standarde dobrog upravljanja i vladavine prava, pa time isti postavljaju de facto smjernice za buduće administrativne prakse unutar država. Ilustrativan primjer za takvo što je predmet Veolia Propreté vs. Arab Republic of Egypt (ICSID Case No. ARB/12/15). $\mathrm{U}$ tom predmetu, investitor Veolia Proprete (francuska kompanija za upravljanje otpadnim vodama), tvrdi da Egipat (država- domaćin) krši svoje obaveze, jer je investicijskim ugovorom (zaključen između navedene kompanije i grada 
Aleksandrije) predviđeno da će svako povećanje operativnih troškova kompanije, bez njihove krivice, biti kompenzirano od strane Egipta, a što Egipat nije učinio nakon što je zakonom povećao iznos minimalne plate u državi za radnike. Investitor, kao tužitelj, tvrdi da je povećavanjem minimalne plate došlo do povećanja njihovih operativnih troškova, odnosno da je Egipat bio dužan kompenzirati tužitelja. Zbog navedenog, države su odgovorile na ograničenje njihove suverene regulatorne moći od strane investicijskih arbitraža na različite načine u posljednjih nekoliko godina. Jedna grupa država u Latinskoj Americi su odgovorili na takvu prijetnju otkazivanjem ili insistiranje na izmjenama nekih svojih investicijskih sporazuma, i povlačenjem iz Konvencije o rješavanju investicionih sporova između država i državljana drugih država (ICSID Konvencija) ili ograničenjem nadležnost ICSID arbitraža. Zemlje u južnoj i istočnoj Africi su umjereniji u svom odgovoru - umjesto odbijanja i otkazivanja investicijskih sporazuma i arbitražnih mehanizama, te države nastoje promovisati, zaključivanjem novih ugovora između sebe, drugačije rješavanje sporova. Druge države su izdale zajedničko tumačenje i pojašnjenje materijalnih odredbi postojećih sporazuma ili su usvojile nove investicione sporazume sa jezikom koji nastoji da usaglasi napetost između načela zaštite investicija i potrebe država za regulatornom diskrecijom (Stears, 2011, s.273).

Posebanaspektdjelovanjainvesticijskihugovoranasposobnostidržavnaregulacije predstavlja situacija kada država- ugovornica pretrpi unutrašnju promjenu režima, odnosno kada autoritativni režim zamjeni demokratski režim, kao što se to desilo u skorije vrijeme u Tunisu i Egiptu (na kraći period). Postavlja se pitanje da li obaveze koje su preuzete investicijskim ugovorima od strane prethodnog (autoritativnog) režima obavezuju nove demokratske vlasti. Naime, sasvim je moguće, a što se i dešava, da elite jedne autoritativno vođene države, zarad svojih interesa, zaključuju po opšti interes štetne ugovore o koncesija, outsourcing-u i dr. sa međunarodnim kompanijama. Dakle, preciznije formulisano, da li pravna sigurnost investitora u takvim situacijama ima prednost nad demokratskim aspiracijama jednog društva, odnosno da li nove demokratske vlasti imaju, po međunarodnom pravu, pravo da raskinu, bez daljnih obaveza prema investitorima, zaključene obaveze i revidiraju stečena prava investitora koja su nepovoljna po cjelokupno društvo? ${ }^{5}$ Odgovor na to pitanje, sa stanovišta međunarodnog prava, je jesan. Promjena unutrašnjeg režima države je irelevantna kada se tiče prirode i sadržaja obaveza koje je država preuzela međunarodnim ugovorom. Ovo slijedi iz tri temeljne pretpostavke međunarodnog prava. Prva, da je država jedinstveni i kontinuirani entitet. Druga, postojeća vlast unutar države ovlaštena je (ima odgovornost) da zastupa državu i svo stanovništvo u svim poslovima. Treća, postojeća vlast unutar jedne države ima neograničenu ovlast da obaveže državu međunarodnim obavezama i za ubuduće (Crawford, 2000, s. 97 i 109). Ovakav pristup je potvrđen i u odluci arbitražnog tribunala za sporove između Irana i Sjedinjenih Američkih Država, nakon što je u Iranu srušen postojeći režim 1979.godine. Dakle, novonastali demokratski režim je uvijek vezan

5 Trenutno postoje dva spora protiv države Egipta pred međunarodnim arbitražama koja su rezultat oduzimanja određenih prava investitorima stečenih nepovoljnim ugovorima po egipatskog društvo koje je zaključila prethodna autoritativna vlast, i to u predmetima: Damac Properties v. Egypt $i$ Veolia v. Egypt. 
istim međunarodnim obavezama koje su ranije vezale prethodni autoritativni režim, što podrazumijeva i postojeće investicijske ugovore (Shaw, 2008, s. 957). Time se ne ostavlja mnogo prostora da novi demokratski režim putem državno-upravne regulacije izvrši nužne socijalne i ekonomske reforme koje bi možda podrazumijevale ukidanje postojećih privilegija stranim investitorima, ukidanje monopola, vraćanje državne imovine od stranih kompanija, povećavanje poreza stranim kompanijama i sl. Takve i slične mjere bi bile zasigurno protivne datim garancijama o" poštenom i pravičnom" (eng. fair and equitable) tretmanu stranim investitorima investicijskim ugovorima, tj. da se neće bitno narušiti postojeći regulatorni okvir koji bi rezultirao direktnom ili indirektnom eksproprijacijom investitora, što bi rezultiralo odlukama arbitražnih tribunala u korist investitora. Kako bi se pronašao izlaz iz takvih, ili sličnih, situacija, arbitražni tribunali bi mogli koristiti koncepte javnog prava koji se koriste u raznim drugim međunarodnim i nacionalnim sudova i tribunala, naročito koncept proporcionalnosti kako bi se uravnotežila prava i pravo na ograničenje prava u javnom interesu (Schill \& Kingsbury, 2010, s.77).

\section{UGROŽAVANJE DEMOKRATSKOG LEGITIMITETA MEĐUNARODNIM INVESTICIJSKIM UGOVORIMA?}

Usko povezano sa pitanjem narušavanja suvereniteta država je i pitanje legitimiteta međunarodnih arbitraža u pogledu izostavljanja demokratskih kontrolnih mehanizama njihovog djelovanja. Prije nego što se okrenemo tom pitanju, nužno je prethodno sagledati sam koncept legitimiteta, pod pretpostavkom da je moderna demokratska država legitimna tvorevina, jer je izraz opće volje, te da je svako njeno djelovanje zapravo djelovanje u javnom interesu.

Legitimitet (lat. lex intimus, lege intimus - najjači zakon) uopšte označava osnovanost nečega na pravu, saglasnost postojanja i djelovanja jedne institucije ili sistema sa pravom. I to ne sa pravom u smislu pozitivnih zakona, već sa pravom u smislu viših, izvornih, opšteprihvaćenih pravila i viših društvenih vrijednosti. Tako, postoji legitimnost društvenog poretka, legitimnost vlasti, legitimnost nekog zahtjeva, postupka itd. Legitimitet političke vlasti podrazumijeva, prije svega, njenu utemeljenost u određenu političku zajednicu na opšteprihvatljivim principima jednog državnog poretka (koji su se kroz istoriju mijenjali), kao i sa preovlađujućim shvaćanjima o pravdi i pravičnosti (Rajović, 2003).

Prije svega, jedna od najobjektivnijih definicija pojma legitimiteta može se pronaći kod Stillman-a (1974,s. 42), koji navodi da je legitimitet izraz kompatibilnosti rezultata djelovanja vlasti sa vrijednosnim sistemom relevantnog sistema ${ }^{6}$. Iz ovog

6 Relevanti sistemi su oni sistemi na koje ili unutar kojih se rezultati djelovanja vlasti osjete. Kako bi vlast bila legitimna njezino djelovanje mora biti kompatibilno sa najmanje četiri nivoa sistema: međunarodni sistem, društvo, grupe unutar društva i pojedinci unutar jednog društva. Svaka vlast ima koristi ukoliko je legitimna. Naime, legitimna vlast može efektivnije vršiti vlast i alocirati istu uz minimalne troškove i napore. Jasno je da djelovanje vlasti ne može sa svim sistemima biti kompatibilno, pa pitanje legitimiteta nije dihotomija-postoji ili ne postoji, nego je pitanje stepena, čime je svaka vlast istovremeno u određenom stepenu legitimna i nelegitimna (Stillman, 1974, s. 43). 
je vidljivo, da legitimitet uveliko ovisi od samog vrijednosnog sistema jednog društva i njegovih segmenata. Dakle, jasno je da je demokratski legitimitet samo jedan od oblika legitimiteta, a prema klasičnom konceptu demokratskog legitimiteta kojeg je uspostavio Carl J. Friedrich, prema kojem je vlast demokratski legitimisana kada uživa povjerenje većine ljudi koji su joj podređeni. Imajući u vidu navedeno, vlast ima demokratski legitimitet ako je od naroda (većine) prihvaćena i podržavana, tj. ako narod na nju pristaje. Taj pristanak se daje na slobodnim, demokratskim izborima, koji jedino mogu biti osnova konstituisanja demokratske predstavničke vlasti i obezbjeđivanja legitimiteta te vlasti (Rajović, 2003).

Međutim, ovo ponovo otvara pitanje ko u suštini vrši suverenu vlast u državi, jer pitanje davanja legitimiteta vlasti od strane većine je odvojeno od samog pitanja efektivnog vršenja vlasti. Prema tradicionalnom shvatanju, kako Digi (2002) primjećuje, suštinu države sačinjava (najviša, suverena) vlast zapovijedanja (nametanje volje drugima), tzv. javna vlast ili suverenitet. Subjekt te vlasti u apsolutističkoj monarhiji je vladalac, koji se na taj način pojavljuje kao država, kao etatizirani nosilaca suvereniteta. U republici (Digi se ovdje referira na francusku republiku) subjekat suvereniteta postaje narod, koji se tako pretvara u državu, u etatiziran narod, u suvereno pravno lice. S toga, Digi ističe, prihvatajući realistički pristup, da je narod kao subjekat suvereniteta, kao suvereno pravno lice, jedna fikcija, jer je sama narodna volja jedna fikcija, pošto je ona stvarno samo volja nekoliko pojedinaca (Digi, 2002, s. 96). On zapaža, dalje, da i kada bi se postigla jednoglasnost, da bi to bila samo volja jednog skupa pojedinaca, to jest pojedinačna volja koja ne bi imala nikakvog prava da se nametne onome koji bi se bunio protiv nje, čime je i sam koncept Rusoa tzv. društvenog ugovora jedna fikcija. Slično tome, Rothbard (2009, s.10 i 16) navodi da država nikada nije bila rezultat društvenog ugovora nego je uvijek bila rezultat osvajanja i eksploatacije, a da, bez obzira na demokratski izabranu vlast, takva vlast opet ne predstavlja sve ljude niti svi ljudi donose odluke-vrše vlast, nego to ipak čini uži krug ljudi-vlast, pa i protiv volje pojedinaca.

Ipak, ideja demokratije, kako navodi Sladeček (2006, s.123) predstavlja jednu od najšire prihvaćenih političkih ideja. Čak i u državama sa malim stepenom uvažavanja individualnih sloboda, demokratija je, barem u njenom formalnom značenju vlasti i vladavine preko opštih izbora i raznih oblika parlamentarizma dobila gotovo neupitni status. Dakle, organi izabrani većinskom voljom građana, posjeduju time demokratski legitimitet, te za svoje odluke odgovaraju građanima koji su ih izabrali.

U tom smislu, kako Saračević (2012) navodi, većina modernih demokratskih sistema podrazumijeva postojanje nekog oblika predstavničkog tijela - parlamenta, kao središnje političke institucije koja predstavlja volju naroda, brani opšte interese i prava građana i služi kao forum za usaglašavanje i raspravu javnih politika U političkoj organizaciji društvene zajednice, sublimacija koncepta predstavljanja je formalizirana kroz predstavnički model demokracije. Legitimitet sistema je opšteprihvaćen kroz postojanje nekog oblika zastupničkog tijela, pri čemu 
se društveni ugovor u praksi ostvaruje kroz djelovanje parlamenta kao glavnog instrumenta predstavljanja i zaštite prava i interesa građana. (s.17 i 21)

Države međunarodnim investicijskim ugovorima delegiraju međunarodnim arbitražama ovlasti da rješavaju međunarodne sporove koji proizilaze iz kršenja prava stranih investitora, a sve zbog efikasnosti i povjerenja u njihovu nepristranost i kredibilnost (Kulick, 2015), koja je posebno bitna za strane investitore koji često nemaju povjerenja u domaće pravosudne institucije. Time se odluke o pravima investitora i obavezama država donose od strane jednog međunarodnog tijela, po pravilima međunarodnog prava, bez mogućnosti uticaja na odluke od strane država, čime se stvara određeni stepen legitimiteta takvih odluka po međunarodnom pravu (Kulick, 2015).

Međutim, međunarodne arbitraže, prilikom donošenja odluka, nužno vrše tumačenje investicijskih ugovora, određujući tako domet prava investitora i granice državne vlasti, odnosno njezine regulacijske mogućnosti. Upravo iz navedenog razloga, jasno je da arbitraže ne odlučuju samo o pravima i obavezama koja su vezana za same trgovačke sporove, nego i o javno-pravnim pitanjima koja su inače rezervisana za domaća sudska tijela koja odlučuju o javno-pravnim sporovima (npr. ustavni sudovi). Tako u navedenim sporovima se odlučuje o ustavnosti postupaka javne vlasti, nakon čega se izriče određena kompenzacija i pristupa se izvršenju dosuđene kompenzacije, a koji elementi navedenog postupka se mogu pronaći i u postupcima pred međunarodnim arbitražama (Kulick, 2015). Dakle, međunarodne arbitraže se bave pitanjima osnovanosti i legalnosti određenih, u javnom interesu donesenih, zakonodavnih akata nacionalnih parlamenata, iako sami svoju nadležnosti crpe iz međunarodnog prava, bez demokratskog legitimiteta. Štaviše, prilikom ocjene o tome da li je određenim zakonodavnim aktom povrijeđeno neko pravo investitora, zagarantovano međunarodnim pravom (investicijskim ugovorom), međunarodne arbitraže često ne uzimaju u obzir pitanje javnog interesa, te svako kršenje prava investitora sankcionišu tako što obavezuju države na isplate naknada štete. U tom smislu, kako Montt (2009, s.125) konstatuje, investicioni ugovori ne zamjenjuju domaće zakone i institucije, oni zamjenjuju domaći sudove za međunarodne arbitraže, uklanjajući de facto značajnu komponentu jurisdikcije nacionalnih sudova. Investicijski arbitražni tribunali bave se i zahtjevima koji bi inače bili u isključivoj nadležnosti nacionalnih ustavnih i vrhovnih sudova. Montt (2009, s.126), u skladu sa svojim prethodnim razmišljanjima, izvodi zaključak da su bilateralni investicijski ugovori stvorili jedan "ekonomski ustav" kojim se uređuju ekonomske aktivnosti stranih investitora, što znači da je delegirana nadležnost na arbitražne tribunale ustavno i upravno-pravnog karaktera. Investicijski arbitražni tribunali imaju moć redefinirati odnos između imovinskih prava i javnog interesa, kao i ovlasti da preispitaju legitimnost državnih aktivnosti i propusta u skladu sa nedefinisanim standardima revizije. Na taj način odluke međunarodnih arbitraža direktno utiču na zakonodavne aktivnosti nacionalnih parlamenata, jer iste 
ograničavaju u autonomiji da pravno regulišu određenu oblast u javnom interesu, za što i posjeduju demokratski legitimitet i mandat, a na štetu stranih investitora.

Sve navedeno je rezultat, a kako to i Sladeček primjećuje (2006), izražene skepse od strane stranih investitora, kao predstavnika neoliberalnog svjetonazora ali, donekle, i vlada država, prema spontanitetu volje građana, kao i efektivnosti i pravičnosti demokratskih institucija, tako da novi konstitucionalizam postepeno i sve djelotvornije zamjenjuje stariju ideologiju narodnog suvereniteta i parlamentarnog odlučivanja. Prema pojedinim kritičarima, uređenja zasnovana na demokratskim procesima odlučivanja su ,inherentno nestabilna“, a vlast u njima je često arbitrarna i nekontrolisana. Smatra se da su demokratije bez dominacije ustavnog liberalizma potencijalno opasne, da podrivaju slobodu i individualna prava, vode do povećane korupcije i zloupotreba vlasti. Dakle, kod takvog rezonovanja, panel sudija, u ovom slučaju međunarodna arbitraža, uzima se kao egzemplar deliberativne racionalnosti, kao najbolje i najpodesnije mjesto za javnu debatu. Kod ovog gledišta riječ je o pomjeranju legitimiteta na stranu pravnog razmatranja u odnosu na narodnu suverenost, odnosno o potiskivanju participativnih, deliberativnih i demokratskih elemenata kao sporednih i manje značajnih, čak i njihovom tretiranju kao prepreka ka uspostavljanju efikasnog liberalnog društvenog sistema. U umjerenoj varijanti ovog pristupa, demokratska volja sagledava se kao instrumentalno najpoželjniji oblik vladavine, ali se participacija ne vrednuje kao intrinzično dobro. Tako se smatra da su građanska participacija i deliberacija korisne u određenim slučajevima, ali da je njihovo proširivanje suvišno u slučaju funkcionalnog i dobro uređenog društva. Na planu ekonomije pojedini liberalistički teoretičari odbacuju regulaciju ekonomske sfere od strane javnosti, kao i uticaj demokratskih institucija kao što je parlament, prepuštajući odluke o ekonomskoj politici elitnom menadžerskom krugu. No većina ovih teoretičara, ne priznaju demokratiju za supstancijalnu vrijednost, nego vrednuju jedino njen proceduralni karakter, tj. uzimaju je tek kao instrumentalnu vrijednost: ravnopravna i fer demokratska procedura izbora vlasti, karakteristična za demokratiju, korisna je jer najčešće ima povoljniji ishod od despotske vlasti (Sladeček, 2006, ss.126-127). Dakle, nedvojbeno je da se takvim gledištima politika, pa i time javni interes podređuje ,potrebama tržišta“, što dovodi do pojave „,demokratije bez demokratije“, u kojoj se vrši progresivna „marketizacija“ rada, zdravstva i obrazovanja ( Podunavac, 2011, s.143).

Ovdje treba naglasiti, da demokratska pravna država, kao društvena tvorevina, ne dozvoljava bilo kome da bude izvan ili iznad demokratskog pravnog sistema i poretka jedne države, što je najveća garancija ljudskih prava i sloboda i brana od bilo kakvih uzurpacija tih prava. „Demokratska pravna država je takva država u kojoj niko nije iznad prava pa ni sam zakonodavac" (Grahovac, 2012, s. 39). Iz

7 Jedan od najboljih primjera takvog postupanja je slučaj Vattenfall AB i dr. protiv SR Njemačke (2012), kada je SR Njemačka morala revidirati svoje propise u oblasti zaštite okoliša, tj. time sniziti standarde zaštite kako ne bi narušila prava investitora. Surprotno navedenom, postoje i odluke međunarodnih arbitraža koje uzimaju u obzir i specifičnu obavezu država da zaštite javni interes (vidi: Continental Casualty protiv Argentine, para. 174 i CME Czech Republic B.V. (The Netherlands) protiv Češke Republike, 2003) 
navedenog je jasno da je nedopustivo da postoji međunarodno tijelo (međunarodne arbitraže) koje utiče na odluke demokratski legitimiranih predstavničkih tijela, a da isto nije podređeno pravnom poretku, koji je stvoren od strane demokratski izabranih predstavničkih tijela. Ipak, izvjesno je da je ekonomska globalizacija u razvijenim tržišnim ekonomijama razbila je model "socijalne države", "države blagostanja", odnosno model tzv. "socijalno-tržišne privrede". Neokonzervativna politička filozofija, odnosno s time povezani neoliberalni model ekonomske politike, idu za smanjenjem javnih rashoda na štetu siromašnih kako bi se demontirala socijalna država (Radošević, b.d., 485). S druge strane, a kako to zagovaraju neoliberalne teorije, pretpostavka da je napredna tržišna ekonomija nužan i dovoljan uvjet za stvaranje demokratske kulture je pogrešna ( Podunavac, 2011, s.140). Zanemarivanje javnog interesa, zarad stvaranja povoljnije klime za investicije, zasigurno ne dovodi do jačanja demokratije, nego do njezinog urušavanja, a nerješavanje socijalnih problema, prije svega od strane parlamenata, može dovesti do rješavanja istih na ulici. Kod ovakvog stanja, jasno je da se demokratske vlasti nalaze u teškoj situaciji, jer sa jedne strane su dužne da djeluju u javnom interesu, dok sa druge strane, dužne su da poštuju svoje međunarodne obaveze.

U tom smislu, interesantno je istaći rezultate nekoliko empirijskih istraživanja koja potvrđuju naprijed navedena teorijska stajališta o tome da strani investitori preferiraju stabilnost i zaštitu imovinskih prava u odnosu na ,previše“ demokratije. Tako Li \& Resnick (2003, s.203) dolaze do zaključka da „,iako veći stepen demokratije pomaže u stvaranju boljeg pravosudnog sistema i vladavine prava, takav veći stepen demokratije ujedno odbija investitore zbog većih ograničenja stranom kapitalu“, te dalje konstatuju da , iako strani investitori se boje narodne volje ipak preferiraju smanjeni nivo korupcije u više demokratskim sistemima“. Ipak, Roberts (2006, s.1) konstatuje da vladavina prava može postojati neovisno o demokratiji, a investitori preferiraju više autokratske režime koji štite njihova imovinska prava nego demokratske režime koji ne poštuju imovinu stranih investitora. S druge strane, Büthe \& Milner ( 2010) ističu da samo demokratske institucije u kombinaciji sa ekonomskom liberalizacijom dovodi do povećanja stranih investicija. Na kraju, istraživanje Busse-a i Hefeker-a (2005) potvrđuje da su stabilnost vlasti, odsutnost unutrašnjih konflikata, osnovna demokratska prava i vladavina prava osnovne determinante za povećanje stranih investicija.

Dakle, vraćajući se na pitanje investicijskih ugovora, iako Izvještaj nezavisnog eksperta Vijeća za ljudska prava UN-a (2015, s.8) sugeriše da se prilikom potpisivanje takvih ugovora „zaobilaze“ nacionalni parlamenti, kao oličenje demokratskog legitimiteta, treba imati na umu da je to pitanje pitanje unutrašnjeg pravnog poretka i odnosa vlasti, kao što je ranije prikazano, dok isto nema nikakvog značaja u međunarodnopravnom prometu. Sve dok je jedan takav ugovor potpisan od strane ovlaštenog zastupnika države, prema odredbama Bečke konvencije, a kao izraz samog suvereniteta države u međunarodnopravnom smislu, pa makar i takav ugovor ograničavao autonomiju djelovanja država i samo djelovanje demokratsko legitimiranih organa, isti se ima poštovati po principu pacta sunt servanda, jer pozivanje na ograničenja u domaćem pravnom poretku nije opravdanje za kršenje 
međunarodne obaveze. Međutim, nesporno je da arbitraža u investicijskim sporovima stvara jedinstven prostor za međunarodnu reviziju javnog demokratskog djelovanja (Cotula, 2017).

\section{ZAKLJUČAK: MEĐUNARODNI INVESTICIJSKI UGOVORI KAO OGRANIČENJE REGULACIJSKE FUNKCIJE DRŽAVE?}

Kako je u prethodnoj analizi prikazano, međunarodni investicijski ugovori doista imaju uticaja na državu u pogledu njenih regulacijskih kapaciteta. Međutim, postavlja se pitanje koliko duboko ide takva intruzija u samu srž države, to jeste u njen suverenitet.

Iako postoje koncepti o ograničenju i ukidanju ideje suvereniteta u pravnoj i političkoj teoriji, ne može se zanemariti činjenica da države i dalje predstavljaju personifikaciju moći i vlasti. Shodno tome, Avramov zaključuje „da država zadržava položaj dominantne jedinke u međunarodnoj sceni sve do danas, bez obzira na promjene koje su se odigrale u svijetu (...), pojednostavljeno posmatran, suverenitet jeste osnovni princip međunarodnog prava, bez kojeg je nemoguća konstrukcija međunarodno-pravnog sistema u sadašnjim društveno-ekonomskim uslovima“ (Knežević - Predić, 2001, s. 48). Princip suverenosti države u međunarodnom pravu podrazumijeva da države imaju jedinu vlast nad svojom teritorijom i da ne podliježu pod nadležnost bilo koje nadnacionalne sile. S toga, običajni princip međunarodnog prava je da država- domaćini i njihove vlade, u njihovoj interakciji s inostranim ulagačima, uživaju veliku slobodu u djelovanju na svojoj teritoriji. ${ }^{8}$ (Al-Adba, 2014, s.58)

Međutim, globalizacija osporava ideju države kao suverenog čuvara javnog interesa. Pod uticajem globalizacije stvoreno je nekoliko međunarodnih sporazuma kojima je prenijetio donošenje odluka sa nacionalnog na međunarodnu nivo. Ta ograničenja države da autonomno donosi odluke u korist javnog interesa posebno su vidljiva kod međunarodnih investicijskih ugovora (Knežević - Predić, 2001). Naime, uvođenjem međunarodnih arbitraža za rješavanje investicijskih sporova, kao međunarodnim tijelima, omogućava se istima da prilikom donošenja odluka ocjenjuju cjelishodnost propisa kojima država nastoji da zaštiti javni interes. Faktički, u pojedinim slučajevima arbitraže su efektivno oborile nacionalne propise. ${ }^{9}$ Dakle, države ugovornice ne mogu više slobodno donositi zakone u javnom interesu bez

8 U tom pogledu u Povelji o Ekonomskim pravima $i$ obavezama država u poglavlju drugom član 1 (Rezolucija usvojena u Generalnoj skupštini UN-a 1974.godine) navodi se, između ostalog, da „, svaka država ima suvereno i neotuđivo pravo da izabere svoj ekonomski sistem...bez miješanja, prisiljavanja ili prijetnji u bilo kojem obliku izvana“, te se dalje navodi da ,, Svaka država ima pravo da reguliše $i$ vrši vlast nad stranim investicijama unutar svoje nacionalne jurisdikcije u skladu sa svojim zakonima i propisima i u skladu sa svojim nacionalnim interesima $i$ ciljevima... " pa shodno tome se ističe da „Međunarodne korporacije ne smiju se miješati u unutrašnja pitanja države-domaćina.“

9 Vidi slučaj Ethyl Corp . protiv. Kanade, gdje je samo pokretanje tužbe pred arbitražom bilo dovoljno da kanadske vlasti povuku zakon koji je bio u javnom interesu. 
brige da će neko arbitražno tijelo utvrditi da je takva regulativna aktivnost suprotna postojećem investicijskom ugovoru (Atik, 1998, ss.229-230). Države su prenijele značajan dio nadležnosti najviših svojih sudova na arbitražne tribunale i izgubile su sposobnost da vrše demkokratski nadzor u sklopu principa podjele vlasti, odnosno da zakonodavnom aktivnošću ograniče ili drugačije urede odnose vezane za strane investicije na svojoj teritoriji (Montt, 2009, s.128). Ovdje treba istaći, opravdano, da arbitraže nemaju tu vrstu legitimiteta da odlučuju o pitanjima koja obuhvataju šire političko-ekonomske implikacije u jednoj državi. Naime, ukoliko jedna demokratski izabrana vlast donosi propise u javnom interesu, postavlja se pitanje kako jedno međunarodno arbitražno tijelo može nadgledati i uticati na takve odluke, bez ikakvog demokratskog legitimiteta, $\mathrm{u}$ tajnosti, bez istinske nezavisnosti ${ }^{10} \mathrm{i}$ bez mogućnosti efektivnog pravnog lijeka protiv odluka. Time, u suštini, arbitražna tijela stvaraju sudsko pravo, jer njihove odluke dovode do opozivanja nacionalnih zakona ili do dodjeljivanja zamašnih iznosa na ime naknade štete investitorima ukoliko se ne izmijeni zakonodavstvo koje je u suprotnosti sa odlukama arbitražnog tijela. U suštini, investicione arbitraže, za razliku od ranijih međunarodnih tribunala i sudova, imaju ulogu kvazi-zakonodavca, a ta uloga je im omogućena zbog široko i neprecizno formulisanih odredbi investicionih ugovora, koje dozvoljavaju arbitražama veliki prostor za tumačenje i diskrecionu ocjenu (Alvarez, 1997, s.531). Tako je u predmetu Continental Casualty Company v. Argentina (ICSID Case No. ARB/03/9 2003) arbitražni tribunal utvrdio da su regulativne mjere Argentine usmjerene ka stabilizaciji nacionalne ekonomije ( izvršena je devalvacija nacionalne valute i određen je fiksni kurs za zamjenu u dolare) u suprotnosti sa važećem investicionim ugovorom. U tom smislu, ,međunarodni arbitražni sistem ima svojevrsnu nedemokratsku suprematiju jer odluke istog ne podliježu zakonodavnoj kontroli“ (Choudhury,2008,s. 789). Uticaj međunarodnih investicionih arbitraža „da ustavno pravo gubi svoju ključnu ulogu sveobuhvatnog regulisanja javne vlasti na datoj teritoriji“" (Walter, 2001, s.194). Cottier i Hertig (2003, ss.303304), u tom smislu, ističu da ustav više ne predstavlja regulativni okvir države. Isti autori naglašavaju da, iako postoje razlike među državama bazirane na moći svake države i ovisno o oblasti regulacije, generalno prenošenje ustavnih funkcija na međunarodne arbitraže dovodi do toga da nacionalni ustavi su samo ,parcijalni ustavi“, nadopunjeni drugim nivoima međunarodne vlasti.

Ipak, kako to pravilno ističe Raustiala (2003), postoje i gledišta prema kojima međunarodni arbitražni sistem, kao i generalno međunarodne ekonomske institucije, ne narušavaju suverenitet država, nego ga čak i pospješuju, jer suverenitet podrazumijeva vrhovnu ovlast da se donese konačna odluka, što je zasigurno još uvijek prerogativ država u međunarodnom pravu. Isti autor navodi da članstvo $u$

10 U nacionalnim pravnim sistemima nezavisnost pravosuđa je garantovana stalnošću sudijske funkcije i finansijskom sigurnošću, međunarodna arbitraža nema nijedan od navedenih elemenata. Naime, iako su arbitri visoko cijenjeni eksperti iz međunarodnog prava i investicijskog prava, tržište arbitara je veoma kompetetivno i naknade su veoma visoke, što utiče na njihove odluke, jer iste moraju biti prihvatljive i investitorima kako bi bili ponovo predloženi kao arbitri u nekom drugom sporu. Kako funkcija arbitra nije stalna, većina paralelno obavlja i profesiju advokata, često zastupajući i sami slučajeve pred međunarodnim arbitražama, čime se stvara prostor za sukob interesa. 
nekoj međunarodnoj ekonomskoj organizaciji ograničava autonomiju djelovanja država, a često je samo članstvo u takvoj organizaciji korisno za samu državu, ali to je odvojeno pitanje od pitanja suvereniteta, jer države u svakom trenutku mogu povući na međunarodne organizacije prenesene nadležnosti, što je opet izraz suvereniteta. U tom pogledu, a primjenjujući rečeno na međunarodne investicijske sporazume, posebno dio koji se odnosi na jurisdikciju arbitraža, treba istaći da su takvi sporazumi svjesni akti suvereniteta država, jer države dobrovoljno i unaprijed daju svoj pristanak, shodno važećem međunarodnom pravu, da u slučaju spora odlučuju nezavisne arbitraže (Carvalho,2016, s.19). S druge strane, svaki međunarodni ugovor predstavlja ograničenje suvereniteta, pa tako nisu ni izuzetak investicijski ugovori. Međutim, ono što je dovelo do „efektivne“ vidljivost takvog ograničenja suvereniteta je mogućnost pokretanja sporova protiv država pred nezavisnim međunarodnim arbitražama. Također, jedinstvena karakteristika investicijskih ugovora je da ne ograničavaju samo suverenitet države spram drugih država, nego što se takvo dejstvo proširuje i u odnosu na strane investitore. Imajući u vidu da su strani investitori najčešće moćne transnacionalne kompanije, afekat takvog ograničavanja može biti značajan, posebno ako se radi o državama u razvoju. U tom pogledu, posebno treba istaći i problem nekonzistentne, i time nepredvidljive, prakse po istim pravnim pitanjima različitih međunarodnih arbitraža, što državama svakako otežava usklađivanje njihovog regulatornog ponašanja (Shan et al., 2008, ss.230-232).

Imajući u vidu sve prethodno navedeno, ovdje treba, ipak, istaći da je "pravo da se reguliše osnovni atribut suvereniteta po međunarodnom pravu" (Mann, 2002). Dakle, vodeći se tom premisom, nužno je zaključiti da investicijski ugovori, a prije svega praksa arbitražnih tribunala, potencijalno (ovisno o odredbama investicijskih ugovora i tumačenja istih od strane arbitražnih tribunal) ograničava regulativnu autonomiju država-domaćina, čime dovodi, barem temporalno (dok je snazi investicijski ugovor), do ograničenja suvereniteta država-domaćina.

\section{Literatura}

1. Aaken, A. (2009). International Investment Law and Rationalist Contract Theory. Working Paper, prezentovan na skupu NYU 22.01.2009. Preuzeto sa: http://www. iilj.org/courses/documents/2009colloquium.session2.aaken.pdf

2. Al-Adba, N. M. (2014). The Limitation of State Sovereignty in Hosting Foreign Investments And The Role of Investor-State Arbitration to Rebalance The Investment Relationship.(doktorska disertacija). University of Manschester-School of Law. Preuzeto sa: https://www.research.manchester.ac.uk/portal/files/54553070/FULL_ TEXT.PDF

3. Alvarez, J. E. (1997). „Critical Theory and the North American Free Trade Agreement's Chapter Eleven“. University of Miami Inter-American Law Review , 28.

4. and Colombia. Springer e-Book. Dostupno na: DOI 10.1007/978-3-319-31217-0 
5. Atik, J. (1998). „Identifying Antidemocratic Outcomes: Authenticity, Self- Sacrifice, and International Trade“, U. PA. J. INT'L ECON. L., 19.

6. Babić, D. (2012). „Pravičan i pošten tretman ulaganja u medunarodnom investicijskom pravu“. Zbornik PFZ, 62, (1-2) 397-416.

7. Binder, C. (2013). Die Grenzen der Vertragstreue im Völkerrecht-am Beispiel der nachträglichen Änderung der Umstände. Heidelberg: Springer.

8. Bonnitcha, J. (2015). Political Change vs. Legal Stability: Problems Arising from the Application of Investment Treaties in Transitions from Authoritarian Rule. Preuzeto sa https://www.iisd.org/itn/2015/02/17/political-change-vs-legal-stabilityproblems-arising-from-the-application-of-investment-treaties-in-transitions-fromauthoritarian-rule/

9. Busse, M. \& Hefeker, C. (2005). „Political Risk, Institutions and Foreign Direct Investment“. HWWA DISCUSSION PAPER, 315.

10. Büthe, T. \& Milner, H. V. (2010). „The Interaction of Domestic and International Institutions: Democracy, Preferential Trade Agreements, and Foreign Direct Investment into Developing Countries“. Workshop on the Politics of Preferential Trade Agreements: Theory, Measurement, and Empirical Applications, Princeton University. Preuzeto sa: https://www.princeton.edu/ pcglobal/conferences/ptas/ BM_pta_paper.pdf

11. Carvalho, P. (2016). „Investor-state arbitration and the rule of law: debunking the myths“. CIS research report; 13.

12. Choudhury, B. (2008). Recapturing Public Power: Is Investment Arbitration's Engagement of the Public Interest Contributing to the Democratic Deficit?" Vanderbilt Journal of Transnational Law, 41, 775-832.

13. Cottier, T. \& Hertig, M. (2003). „The Prospects of 21st Century Constitutionalism“. Max Planck Yearbook of United Nations Law, 7, 261-304.

14. Cotula, L. (2014). Do investment treaties unduly constrain regulatory space? Preuzeto sa: http://www.qil-qdi.org/investment-treaties-unduly-constrain-regulatory-space/

15. Cotula, L. (2017). „Democracy and International Investment Law“. Leiden Journal of International Law, 30, 351-382. Doi: 10.1017/S0922156517000152

16. Crawford, J. (2000). „Democracy and the Body of International Law“. U: G. Fox, \& B. Roth (ur.). Democratic Governance and International Law. Cambridge University Press.

17. Digi, L. (2002). „Preobražaji javnog prava“. U: S. Lilić (ur.), Pravne teme (ss.91-98). Beograd: Magna Agenda.

18. Ding, J. (2016). „Enforcement In International Investment And Trade Law: History, Assessment, And Proposed Solutions“. GEORGETOWN JOURNAL OF INTERNATIONAL LAW, 1137-1165.

19. Dolzer, R. (2005a). „The impact of international investment treaties on domestic administrative law“. New York University Journal of International Law and Politics, 37, 953-971. 
20. Douglas, Z. (2009). The International Law of Investment Claims. Cambridge: Cambridge University Press.

21. Duguit, L. (1929.) Preobražaji javnog prava. Beograd: Geca Kon.

22. Džinić, J. (2011). „Regulacijska tijela i regulacija: neki problemi u pogledu (ne) donošenja uredbi za izvršenje zakona“. HKJU - CCPA, 11(3), 651-680.

23. Forum za javnu upravu-Friedrich Ebert Stiftung, ured za Hrvatsku (2014). Od javnog prema privatnom? Privatizacija i outsourcing javnih usluga. Zagreb: Friedrich Ebert Stiftung.

24. Franck, S. D. (2005). „The legitimacy crisis in investment treaty arbitration: privatizing public international law through inconsistent decisions“. Fordham Law Review, 73, 1521-1625.

25. Grahovac, M. (2012). „Pojam i društveni značaj demokratske pravne države i vladavine prava“. Škola biznisa, 3, 38-42.

26. Johnson, L \& Volkov, O. (2014). State Liability for Regulatory Change: How International Investment Rules are Overriding Domestic Law. Preuzeto sa: https:// www.iisd.org/itn/2014/01/06/state-liability-for-regulatory-change-how-internationalinvestment-rules-are-overriding-domestic-law/

27. Kingsbury, B. \& Schill, S. (2011). „Investor-State Arbitration as Governance: Fair and Equitable Treatment, Proportionality and the Emerging Global Administrative Law“. IILJ Working Paper, 6

28. Knežević-Predić, V. (2001). Ogled o suverenosti: Suverenost i Evropska unija. Beograd: Institut za političke studije.

29. Koprić, I. (b.d). Regulacija službi od općeg interesa. Preuzeto sa https://www. academia.edu/11381287/Regulacija_slu\%C5\%BEbi_od_op\%C4\%87eg_interesa

30. Kulick, A. (2015). „Investment Arbitration, Investment Treaty Interpretation, and Democracy“. Cambridge Journal of International and Comparative Law, 4(2)

31. Li, Q. \& Resnick A. (2003). „Reversal of Fortunes: Democratic Institutions and Foreign Direct Investment Inflows to Developing Countries“. International Organization, 57, 175-211.

32. Lilić, S. (2014). Upravno i upravno procesno pravo.Beograd: Pravni fakultet Univerziteta u Beogradu.

33. Lozina, D. \& Klarić M. (2012). „Javna uprava suvremene države u promijenjenim okolnostima“. Zbornik radova Pravnog fakulteta u Splitu, 49(1), 23-37.

34. Lukić, R. D. \& Košutic, B. (1979). Uvod u pravo. Beograd: Naučna knjiga.

35. MacNeil, I. (2005). An Introduction to the Law on Financial Investment. Oxford: Hart Publishing.

36. Majone, G. (1996). „Regulation and its modes“. U: Giandomenico, M. (ur.), Regulating Europe, New York: Routlegde.

37. Mann, H. (2002). The Right of States to Regulate and International Investment Law. Expert Meeting on the Development Dimension of FDI: Policies to Enhance the Role of FDI in Support of the Competitiveness of the Enterprise Sector and the Economic Performance of Host Economies, Taking into Account the Trade/Investment Interface, 
in the National and International Context. Preuzeto sa: http://www.iisd.org/pdf/2003/ investment_right_to_regulate.pdf

38. Montt, S. (2009). State Liability in Investment Treaty Arbitration: Global Constitutional and

39. Muhić, F. (2002). Teorija države i prava. Sarajevo: Magistrat.

40. OECD. (2004). ,'Indirect Expropriation' and the 'Right to Regulate' in International Investment Law”. OECD Working Papers on International Investment, 2004/04. OECD Publishing.

41. Podunavac, M. (ur.). (2011). Ustav i demokratija u procesu transformacije. Beograd: Zbornik radova sa međunarodne naučne konferencije.

42. Potesta, M. (2013). „Legitimate expectations in investment treaty law: Understanding the roots and the limits of a controversial concept“". ICSID Review, 28, 88-122.

43. Pusić, E. (1989). Društvena regulacija. Zagreb: Globus i Pravni fakultet

44. Radošević, D. (b.d.). „Demokratski legitimitet i društveni konsenzus u uvjetima ekonomske recesije“. Ekonomija/Economics, 9(3), 483-501.

45. Rajović, R. (2003). Ustav i prava građana za stručne škole i gimnaziju. Beograd: Zavod za udžbenike i nastavna sredstva.

46. Raustiala, K. (2003). „Rethinking the sovereignty debate in international economic law“. Journal of International Economic Law, 6(4), 841-878.

47. Roberts, T. (2006). Political Institutions and Foreign Direct Investment in Developing Countries: Does policy stability mean more to investors than democracy or property rights? Preuzeto sa: http://tercer.bol.ucla.edu/workshop/roberts06.pdf

48. Roeder, R. W. (2016). Foreign Mining Investment Law: The Cases of Australia, South Africa

49. Rothbard, M. N. (2009). Anatomy of the State. Auburn: Ludwig von Mises Institute.

50. Saračević, N. (2012). „Uloga Parlamenta u modernim demokracijama“. U Gavrić, S. \& Banović, D. (ur.), (2012). Parlamentarizam u Bosni i Hercegovini. Sarajevo: Sarajevski otvoreni centar/ Fondacija Friedrich Ebert.

51. Schill, W. \& Kingsbury, B. (2010). Public Law Concepts To Balance Investors' Rights With State Regulatory Actions In The Public Interest-The Concept Of Proportionality. Oxford: Oxford University Press.

52. Schneiderman, D. (2013). Resisting Economic Globalization: Critical Theory and International Investment Law. New York: Palgrave Macmillan.

53. Schreuer, C. (b.d). The Future of Investment Arbitration. Preuzeto sa: http://www. univie.ac.at/intlaw/pdf/98_futureinvestmentarbitr.pdf

54. Shan, W.; Simons, P. \& Singh, D. (ur.) (2008). Redefining Sovereignty in International Economic Law. Oxford: Hart Publishing.

55. Shaw, M. (2008). International Law (6th ed.). Cambridge: Cambridge University Press.

56. Sládeček, M. (2006). „Problem legitimnosti demokratije“. Filozofija i društvo, 2, 122 134. 
57. Sornarajah, M. (2010). The International Law on Foreign Investment (Third ed.). Cambridge: Cambridge University Press.

58. Spears, S. (2011). „Making way for the public interest in international investment agreements". U: Brown S. i Miles K.(ur), Evolution in investment treaty law and arbitration (ss. 271-298). Cambridge: Cambridge University Press.

59. Stillman, P. G. (1974). „The Concept of Legitimacy“. Polity, 7(1), 32-56.

60. Šijaković, I. (2008). Sociologija: Uvod u razumevanje globalnog društva. Treće dopunjeno izdanje. Banja Luka: Univerzitet u Banjoj Luci, Ekonomski fakultet.

61. UNCTAD. (2012). Fair And Equitable Treatment. New York and Geneva: United Nations. Preuzeto sa: http://unctad.org/en/Docs/unctaddiaeia2011d5_en.pdf

62. Walter C. (2001). „Constitutionalizing (Inter)national Governance - Possibilities for and Limits to the Development of an International Constitutional Law“. German Yearbook of International Law, 44.

63. Yannaca-Small, K. (2010). Arbitration under international investment agreements: a guide to the key issues. New York: Oxford University Press.

64. Yannaca-Small, K. (2006). „Interpretation of the Umbrella Clause in Investment Agreements“. International Investment Law: Understanding Concepts and Tracking Innovations. OECD. Preuzeto sa: https://www.oecd.org/investment/ internationalinvestmentagreements/40471535.pdf

\section{Praksa međunarodnih arbitraža:}

1. AES v. Hungary, ICSID Case No. ARB/07/22, Award, Sept. 23, 2010

2. CME Czech Republic B.V. (The Netherlands) v. Czech Republic (2003). Final Award, Separate Opinion of Sir Ian Brownlie. UNCITRAL

3. Continental Casualty Company v. Argentine Republic. 2008 Award. ICSID Case No. ARB/03/9. Preuzeto sa: https://www.italaw.com/cases/329

4. EDFI v. Argentina, ICSID Case No. ARB/03/23 Award, June 11, 2012

5. Enron and Ponderosa v Argentina, Award of 22 May 2007, ICSID Case No ARB/01/3, Preuzeto sa $:<\mathrm{http}: / /$ ita.law.uvic.ca/documents/Enron-Award.pdf $>$

6. LG\&E Energy Corp., LG\& E Capital Corp., and LG\&E International, Inc.v. Argentine Republic. ICSID Case No. ARB/02/1, Preuzeto sa: https://www.italaw.com/cases/621

7. Occidental Exploration and Production Company v. Ecuador, LCIA Case No. UN 3467, Final Award, July 1, 2004. Preuzeto sa: https://www.italaw.com/cases/ documents/762

8. Total v. Argentina, ICSID Case No. ARB/04/1, Decision on Liability, Dec. 27, 2010

9. Técnicas Medioambientales Tecmed, S.A. v. The United Mexican States. ICSID Case No. ARB (AF)/00/2. Preuzeto sa: https://www.italaw.com/cases/documents/1088

10. Vattenfall $A B$ and others v. Federal Republic of Germany. (2012). ICSID Case No. ARB/12/12.

11. Veolia Propreté vs. Arab Republic of Egypt .ICSID Case No. ARB/12/15. 


\section{THE RESTRICTION OF THE REGULATORY FUNCTION OF THE STATE THROUGH INTERNATIONAL INVESTMENT TREATIES}

The process of globalization puts states, and therefore their administrations, against new challenges, which can only be overcome by the mutual cooperation of states and other subjects of international law. The interdependence of these entities in the global economic race and the struggle for investment has also produced new forms of administrative regulation, primarily with the emergence of interstate bilateral and multilateral investment contracts, which essentially affect the administrative and legal sphere of the state, limiting both, the scope and quality of the state's regulatory capacity. Nevertheless, one cannot ignore the fact that states continue to be a personification of power.

On the other hand, the restrictions to the autonomy of states in making decisions for the benefit of the public interest are particularly visible in international investment treaties. International arbitrations, which are the forum for dispute settlements arising from the International Investment Treaties, assess the appropriateness of the regulations by the state in order to protect the public interest. International investment arbitrations, unlike the previous international tribunals and courts, have the role of a quasi-legislator, and this role is made possible by the wide and imprecisely formulated provisions of investment contracts, which allow arbitrations a great deal of interpretation and discretionary assessment. All this seriously restrict the regulatory capacity of the state.

Key words: sovereignty, regulation, state, international investment treaties, international investment arbitration 